\title{
Serodiagnosis of Toxocariasis by ELISA test using anti- T. canis IgG antibodies in stray dogs compared to PCR
}

\author{
N.I. Jarad ${ }^{1 *}$, A.K. Abbas² and N.N. Aảiz \\ ${ }^{1}$ Department of Veterinary Microbiology, ${ }^{2}$ Department of Parasitology, College of Veterinary Medicine, \\ University of Al-Qadisiyah, Al-Qadisiyah, ${ }^{3}$ Department of Veterinary Microbiology, College of Veterinary Medicine, \\ University of Baghdad, Baghdad, Iraq, "email: noor.jarad@qu.edu.iq
}

(Received June 16, 2018; Accepted September 3, 2018)

\begin{abstract}
Toxocara (T.) canis is a nematode parasite of canines; belong to the Ascarididae family, which accidentally infected humans. Puppies expel the eggs with the feces from the fourth week of the life cycle. This study is the first study in Iraq for detection seroprevalence in stray dogs and extended from January to September 2017. Our study was aimed to investigate the seroprevalence of $T$. canis infection in stray dogs from different areas in the Al-Diwaniya province, Iraq to detection of specific IgG antibodies to T. canis compared to Conventional PCR technique with the effect of the risk factor. One hundred of the blood sample and one hundred of a faecal sample of same dogs after shooting were studied using indirect ELISA test and PCR. The result revealed that $71 \%$ of the dogs had a seropositive result for this parasite by ELISA test. Dog age is an important factor and affects seroprevalence, were shown that positive rate in adult dogs was more $83.05 \%$ than the young dogs $53.65 \%$, while no significant between dogs according to sex. PCR technique showed $58 \%$ of dogs were positive for internal transcribed spacer 1 (ITS1) ribosomal RNA. The sensitivity and specificity of ELISA test was 79 and $40 \%$ respectively.
\end{abstract}

Keyword: Dogs, Toxocara canis, ELISA, PCR

Available online at http://www.vetmedmosul.com

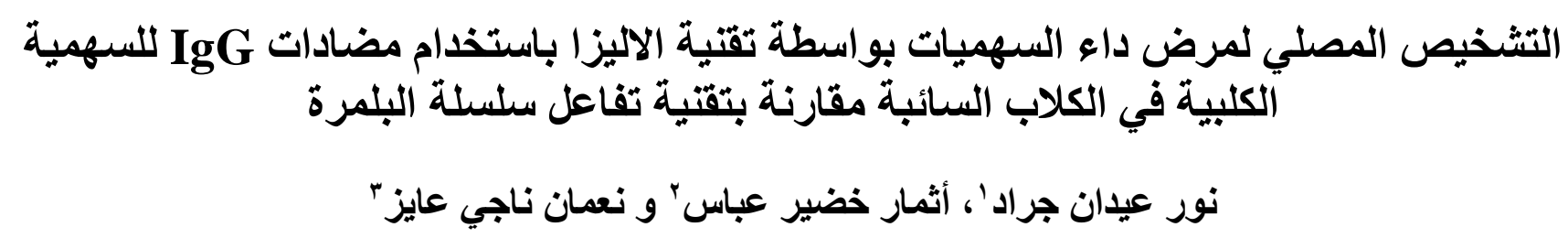

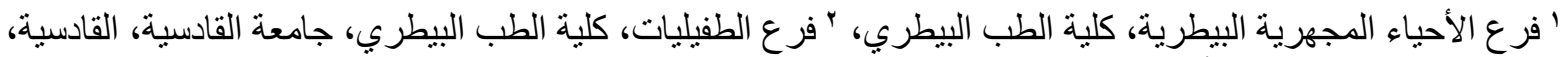

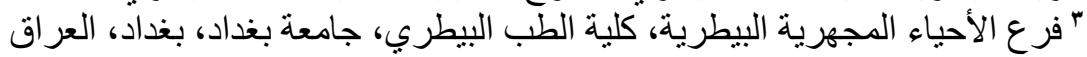

السهية الكلبية هو طفيلي الديدان الخيطية في الكلاب تنتمي إلى عائلة Ascarididae. السهية الكلبية التي تصيب البشر بطريق الخطأ.

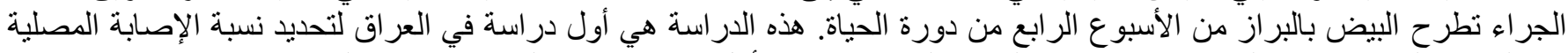

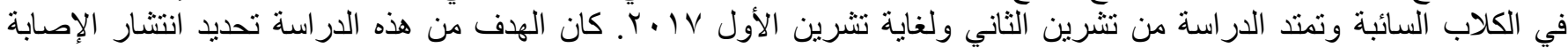

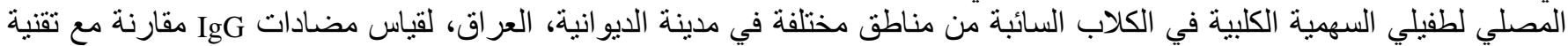

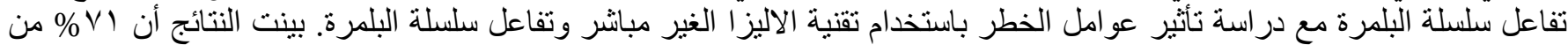

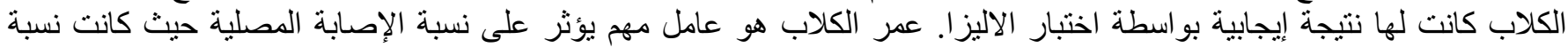

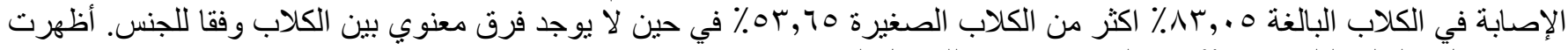

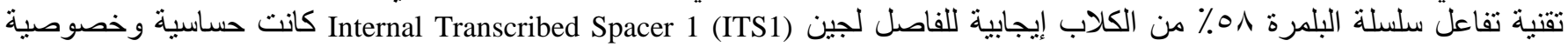

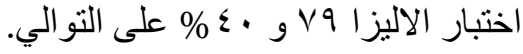




\section{Introduction}

Toxocara canis is parasite causes a disease called toxocariasis. Toxocara canis is causing parasitic intestinal infection of domestic animals (1). In humans, the roundworms are an etiological factor of ocular and visceral larva migrans (2). $T$ canis have an oral-faecal transmission cycle, infective eggs from soil that contain on (playgrounds, sandpits and gardens) from direct contact with dogs, or raw vegetables or infected unwashed hands (3). The infected young puppies usually show acute clinical signs of toxocariasis. The typical clinical signs are a loss of condition, poor growth and sometimes show potbelly. The worms may be passed in the faeces or vomited. Also, may be appearing clinical sign as constipation, vomiting, diarrhea, and flatulence (4). Infected dogs by Toxocara canis can be detected from clinical symptoms and case history. The final diagnosis occurs by finding eggs (characterized by pitted shells, dark brown in color and thick) in feces (5). Indirect ELISA methods can detect IgG antibodies against TES Ag (IgG TES-ELISA) that could be considered diagnosis tool for toxocariasis (6). However, cross-reaction is common among the helminths (7).

\section{Materials and methods}

\section{Collection of samples}

A total of 100 blood sample that collected from the heart and jugular vein of stray dogs after shooting, and 100 fecal samples were collected from the same animal. A blood sample was put in gel tube, while fecal samples put in a container with information include date, age and sex.

\section{Serum preparation and ELISA test}

Centrifugation separated the serum at 3000 round per minute for 10 minutes, the serum aspirated carefully by pipette into dry, sterile and labelled test tubes, storage at $20^{\circ} \mathrm{C}$ until used. Indirect ELISA kit was purchased from MyBioSource company in America country were used for detection anti- T. canis IgG antibodies in serum samples.

\section{Molecular study}

For polymerase chain reaction, the primer was designed in this study using complete sequence Toxocara canis isolate, internal transcribed spacer 1, 5.8S ribosomal RNA gene from GenBank: KF577856.1. These primers were provided by Bioneer Company, Korea showing in the table (1).

Genomic DNA was extracted from 100 fecal samples using AccuPrep®Stoolused kit from Bioneer company in Korea, and performed based on company directions. The extracted DNA were tested by apparatus called Nanodrop spectrophotometer (THERMO, made in the USA). These apparatus measures the DNA concentration and purity by reading the absorbance at $(260 / 280 \mathrm{~nm})$. This technique was carried out according to company instructions as in table (2). Then PCR products were analyzed by agarose gel electrophoresis.

Table 1: Gene, primer, sequence and PCR product size

\begin{tabular}{|c|c|c|}
\hline Primer & Sequence & $\begin{array}{l}\text { PCR } \\
\text { product } \\
\text { size }\end{array}$ \\
\hline T. canis & $\begin{array}{ll}\text { F } & \text { CTCACCTAGCTATTGCCCGG } \\
\text { R } & \text { CCTTGGCAAGGTACGCTGTA }\end{array}$ & $516 \mathrm{bp}$ \\
\hline
\end{tabular}

Table 2: The PCR thermocycler constructs reaction conditions

\begin{tabular}{lccc}
\hline PCR Step & Temp. & Time & Repeat \\
\hline Initial denaturation & $95^{\circ} \mathrm{C}$ & 5 minutes & 1 \\
Denaturation & $95^{\circ} \mathrm{C}$ & 30 seconds & 30 cycle \\
Annealing & $58^{\circ} \mathrm{C}$ & 30 seconds & \\
Extension & $72^{\circ} \mathrm{C}$ & 60 seconds & \\
Final extension & $72^{\circ} \mathrm{C}$ & 5 minutes & 1 \\
Hold & $4^{\circ} \mathrm{C}$ & forever & - \\
\hline
\end{tabular}

\section{Sensitivity and specificity calculation}

In this study, sensitivity and specificity of ELISA for $T$. canis infection versus PCR result were calculated according to (8) (Table 3).

Table 3: Explained sensitivity and specificity calculation

\begin{tabular}{lllll}
\hline & & PCR & & \multirow{2}{*}{ Total } \\
\cline { 3 - 4 } & & Positive & Negative & \\
\hline \multirow{2}{*}{ ELISA } & Positive & true + ve & false +ve & test +ve \\
& Negative & false -ve & true -ve & test -ve \\
\hline Total & & & & \\
\hline
\end{tabular}

*Sensitivity $\left.=\frac{\text { True }+}{[\text { True+ }]+[\text { False- }]}\right] x 100$

* Specificity $=\frac{\text { True }}{(\text { True })+(\text { False })]} \times 100$

\section{Statistical analysis}

It was done by social science for the statistical package (SPSS) version 17 for Windows software and Microsoft Excel 2010. Differences between groups were used test of the chi-square at $(\mathrm{P} \leq 0.05)$.

\section{Results}

One hundred blood samples were analysis revealed that $71 \%$ of the dogs had seropositive result for this parasite. The infection rate in males was $79.16 \%$ higher than the females $63.46 \%$ (Table 4 ). 
Table 4: Show rates of Toxocariasis infection in dogs by ELISA according to sex

\begin{tabular}{lccc}
\hline Sex & $\begin{array}{c}\text { No. of examined } \\
\text { samples }\end{array}$ & $\begin{array}{c}\text { No. of Positive } \\
\text { samples }\end{array}$ & $\%$ \\
\hline Males & 48 & 38 & 79.16 \\
Females & 52 & 33 & 63.46 \\
\hline Total & 100 & 71 & 71 \\
\hline$x^{2}: 0.165$ & $\mathrm{p}$ value: 0.684 (non-significant difference $(\mathrm{p}>$ \\
$0.05)$. & & & \\
\end{tabular}

Our study founded the percentage of infected adult dogs by toxocariasis was $(83.05 \%)$ while the young dogs were $(53.65 \%)$ as in Table (5).

Table 5: Rates of Toxocariasis infection in dogs by ELISA according to ages.

\begin{tabular}{lccc}
\hline Age & $\begin{array}{c}\text { No. of examined } \\
\text { samples }\end{array}$ & $\begin{array}{c}\text { No. of Positive } \\
\text { samples }\end{array}$ & $\%$ \\
\hline Young & 41 & 22 & 53.65 \\
Adult & 59 & 49 & 83.05 \\
\hline Total & 100 & 71 & 71 \\
\hline$x^{2}: 10.150$ p value: 0.0014 (significant difference $\mathrm{p}<0.05$ )
\end{tabular}

The total results of PCR technique showed that out of 100 dogs fecal samples 58\% were positive for the gene of the ribosomal RNA of the ITS1 (Figure 1).

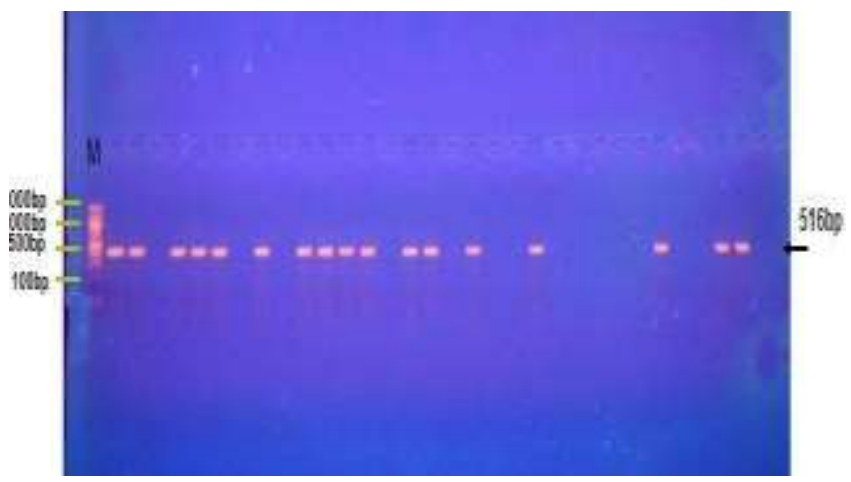

Figure 1: Agarose gel electrophoresis image show the PCR product analysis of internal transcribed spacer 1 (ITS1) ribosomal RNA gene in Toxocara canis of DNA extracted from faecal samples of stray dogs, where Lane (M) ladder (2000-100bp), lane 1, 2, 4, 5, 6, 8, 10, 11, 12, 13, 15, 16, $18,21,27,30,31$ shown positive Toxocara canis at (516bp) PCR product size from 33 sample.

The specificity and sensitivity of serodiagnosis of toxocariasis in dogs are compared to PCR was 40 and $79 \%$ respectively as in table (6).
Table 6: Represented Sensitivity and Specificity of ELISA for $T$. canis infection versus PCR result

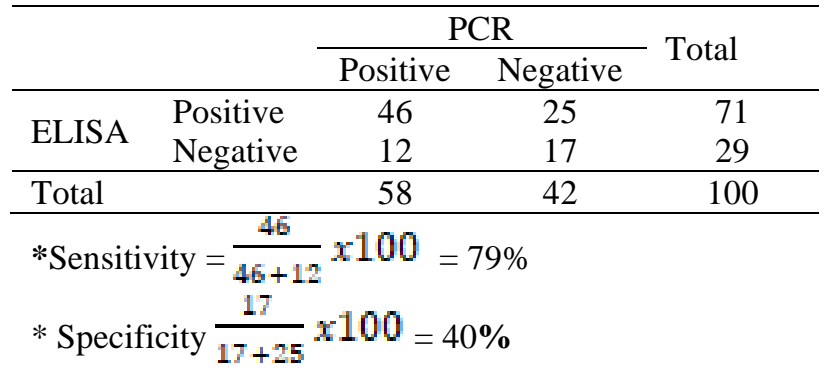

\section{Discussion}

In many reports that related to toxocariasis in dogs are diagnosed by the detection of the parasite eggs (9). In the present study investigated the $T$. canis parasite in stray dogs serologically using the indirect ELISA test to detect IgGELISA.

This study is the first time that studies the seroprevalence of Toxocara canis in stray dogs from the different region of the Al-Diwaniya province, south of Iraq. The seroprevalence of Toxocara in stray dogs was $71 \%$. The seroprevalence was higher than those reported by Rubel et al. (10) who recorded $22 \%$ in the middle-income region and $40 \%$ in a low-income region out of 105 in Argentina. Also in Mexico by Garcia et al. (11) recorded $56.1 \%$. Serological of anti-T. canis IgG recorded in Brazil was $82.7 \%$ (12) which is higher than that recorded in the present study. In Argentina, the seroprevalence was reported high rate $86.95 \%$ had positive serology for this parasite (13). The indirect ELISA test in only measured antibodies against $T$. canis and the presence of $\mathrm{IgG}$ antibodies does not mean the animal was harbor the infection at that specific time. A study of (11) mentioned that the anti- Toxocara antibodies ( $\mathrm{IgG}$ ) may remain for a long time, even in the absence of the disease, therefore, a positive result by ELISA-IgG cannot distinguish between past and current.

According to sex, no differences in seroprevalence were observed between males and female dogs, similar results previously reported by Garcia et al. (11). However, there is data that showed higher seroprevalence in male dogs (12). Moreover, it is important to consider that female dogs (bitch) keep larval stages in their bodies' tissues during pregnancy periods which infect their puppies after birth (14).

The rate of infection in the present study varied according to ages. It was significantly higher among adult dogs $83.05 \%$, and the lowest rate in young dogs $53.65 \%$. These results may be because dogs are constantly getting infected with $T$ canis eggs from the contaminated 
environment as they grow up. Also, the ELISA test in this study only measured antibodies against $T$ canis, and the presence of antibodies does not mean the animal was sick at that specific time. Also, in the adult dogs the most common the worms developed in the small intestine to the adult stage. Wherever, the larvae become latent in the host tissue (15). The findings agree with previous studies in Mexico by Garcia et al. (11) who recorded high titers of antibodies of the anti-T. canis in adult dogs' more than young dogs. A study of Silva et al. (12) recorded that adult dogs are positive serologically more than the young.

The serological technique does not need a long time and more sensitive as compared with a classical parasite examination of faecs of $T$. canis. There only the one preventive factor in using ELISA is not easy for clinical laboratories and small-scale research (16).

In this study, the sensitivity and specificity for toxocariasis in dogs serological compared to PCR were recorded $79 \%$ and $40 \%$ respectively. A study of Jin et al (17) recorded sensitivity and specificity of the ELISA were $79 \%$ and $40 \%$, respectively. A study of (18) compared sensitivity of dot-ELISA, and the standard ELISA were Sensitivity $100 \%$ for both, while specificity $95 \%$ and $90 \%$ for dot-ELISA and the standard ELISA respectively. A study of (19) compared between using of IgG-ELISA and IgG4-ELISA, the specificities were 36 and $78.6 \%$ respectively, the sensitivity of the IgG-ELISA was $97.1 \%$, while that of the IgG4-ELISA was $45.7 \%$.

Detection of the toxocariasis serologically has crossreactions with other helminthiases, that make it less specific (20), such as geohelminthes, Fasciola, and Strongyloides $(20,21)$. Furthermore, Echinococcus, Schistosoma and Taenia (22). The serodiagnosis is considered a problem in tropical areas because of the most common mixed parasitic infections.

\section{Reference}

1. Overgaauw PAM. Prevalence of intestinal nematodes of dogs and cats in the Netherlands. Vet Quart. 1997;19:14-17. DOI: $10.1080 / 01652176.1997 .9694730$

2. Hotez P, Fenwick A, Savioli L, Molyneux DH. Rescuing the bottom billion through control of neglected tropical diseases. Lancet. 2009;373:1570-1575. DOI:10.1016/S0140-6736(09)60233-6.

3. Wolfe A, Wright IP. Human toxocariasis and direct contact with dogs. Vet Rec. 2003;152:419-422. DOI:10.1136/vr.152.14.419

4. Bowman DD. Georgi's parasitology for veterinarians. $9^{\text {th }}$ ed. Washington: Library of Congress Cataloging; 2009. 202 p. https://epdf.pub/georgis-parasitology-for-veterinarians-9thedition.html

5. Lindsay DS, Blagburn BL. Practical treatment and control of infections caused by canine gastrointestinal parasites. Vet Med. 1996;90(5):441-55.

6. Smith HV, Noordin R. Diagnostic limitations and future trends in the serodiagnosis of human toxocariasis. In: Holland CV, Smith HV. eds. Toxocara: The enigmatic parasite. Oxford: CABI Publishing; 2006. p.113-126. DOI: $10.1079 / 9781845930264.0089$
7. Lozano MJ, Martin HL, Diaz SV, Manas AI, Valero LA, Campos BM. Cross-reactivity between antigens of Anisakis simplex S.L. and other ascarid nematodes. Parasite. 2004; 11: 219-223. DOI: $10.1051 /$ parasite/2004112219

8. Forbes BA, Sahm DF, Weissfeld AS. Diagnostic Microbiology. $12^{\text {th }}$ ed. Philadelphia: Elsevier; 2007. p.1056.

9. Mohamad S, Azmi NC, Noordin R. Development and evaluation of a sensitive and specific assay for diagnosis of human toxocariasis by use of three recombinant antigens (TES-26, TES-30USM, and TES-120). J Clin Microbiol. 2009;47(6):1712-1717. doi: 10.1128/JCM.00001-09

10. Rubel D, Zunino G, Santillán G, Wisnivesky C. Epidemiology of Toxocara canis in the dog population from two areas of different socioeconomic status, Greater Buenos Aires, Argentina. Vet Parasitol. 2003;115:275-286. DOI:10.1016/s0304-4017(03)00185-7

11. Gracia LT, Serrano AB, Valencia GL, Tamayo S. Seroprevalence and risk factors associated with larva migrans of Toxocara canis in dogs from Mexicali Baja California, Mexico. J Anim Vet Adv. 2007;6(2):198-202. doi=javaa.2007.198.202

12. Silva SC, Mendonc LR, Silva NDS, Dattoli VCC, Alcântara NM, Barrouin SM. Seroprevalence and risk factors for canine toxocariasis by detection of specific IgG as a marker of infection in dogs from Salvador, Brazil. Acta Tropica 2011;120: 46-51. https://doi.org/10.1016/j.actatropica.2011.05.011

13. Garcia LD, Lopez M, Bojanich MV, Laffont HM. Detection of IgG anti Toxocara Canis in dogs from Corrientes Province, Argentina. Revista Veterinaria. 2012;23(1):69-70.

14. Quiroz H. Parasitology enfermedades parasitarias de animals Domesticos / Parasitology and Parisite Disease of Domestic Animals. Editorial Limusa. 1999. P.1053. http://revistas.unne.edu.ar/index.php/ vet/article/view/1820

15. Overgaauw PAM. Prevalence of intestinal nematodes of dogs and cats in the Netherlands. Vet Q. 1997;19:14-17. 10.1080/01652176.1997.9694730

16. Elefant GR, Shimizu SH, Sanchez MCA, Jacob CMA, Ferreira AW. A serological follow-up of toxocariasis patients after chemotherapy based on the detection of $\operatorname{IgG}, \operatorname{IgA}$ and $\operatorname{IgE}$ antibodies by enzymelinked immunosorbent assay. J Clin Lab Anal. 2006;20(4):164-72. DOI: $10.1002 /$ jcla.20126

17. Jin Y, Shen C, Huh S, Sohn WM, Choi MH, Hong ST. Serodiagnosis of toxocariasis by ELISA using crude antigen of Toxocara canis larvae. Korean J Parasitol. 2013;51(4):433-439. DOI.10.3347/kjp.2013.51.4.433

18. Roldan W, Cornejo W, Espinoza Y. Evaluation of the dot enzymelinked immunosorbent assay in comparison with standard ELISA for the immunodiagnosis of human toxocariasis. Mem Inst Oswaldo Cruz Rio de Janeiro. 2006;101(1):71-74. DOI: 10.1590/S007402762006000100013 .

19. Noordin R, Smith HV, Mohamad S, Maizels RM, Fong MY. Comparison of IgG-ELISA and IgG4-ELISA for Toxocara serodiagnosis. Acta Tropica. 2005;93(2005):57-62. DOI: 10.1016/j.actatropica.2004.09.009

20. Jacquier P, Gottstein B, Stingelin Y, Eckert J. Immunodiagnosis of toxocariasis in humans: evaluation of a new enzyme-linked immunosorbent assay kit. J Clin Microbiol. 1991;29:1831-1835. https://jcm.asm.org/content/29/9/1831.short

21. Romasanta A, Romero JL, Arias M, Sanchez AR, Lopez C, Suarez JL, Diaz P, Diez BP, Morrondo P, Paz SA. Diagnosis of parasitic zoonoses by immunoenzymatic assays-analysis of cross-reactivity among the excretory/secretory antigens of Fasciola hepatica, Toxocara Canis, and Ascaris suum. Immunol Invest. 2003;32:131142. DOI: $10.1081 / \mathrm{IMM}-120022974$.

22. Ishida MM, Rubinsky EG, Ferreira AW, Hoshino SS, Vaz AJ. Helminth antigens (Taenia solium, Taenia crassiceps, Toxocara canis, Schistosoma mansoni and Echinococcus granulosus) and crossreactivities in human infections and immunized animals. Acta Trop. 2003;89:73-84. DOI:10.1016/j.actatropica.2003.09.005 